Article

\title{
Holistic Approaches to Develop Sustainability and Research Competencies in Pre-Service Teacher Training
}

\author{
Silvia Albareda-Tiana *(D), Salvador Vidal-Raméntol, Maria Pujol-Valls and \\ Mónica Fernández-Morilla \\ Faculty of Education, Universitat Internacional de Catalunya, 08017 Barcelona, Spain; svidal@uic.es (S.V.-R.); \\ mpujolv@uic.es (M.P.-V.); mfernandezm@uic.es (M.F.-M.) \\ * Correspondence: salbareda@uic.es; Tel.: +34-932541800 or +34-93504200
}

Received: 31 August 2018; Accepted: 8 October 2018; Published: 15 October 2018

\begin{abstract}
Since the Sustainable Development Goals (SDGs) came into effect, both UNESCO and other international organisations recommend empowering youth to implement the SDGs in universities. Getting started with the SDGs at university level is of special relevance in pre-service teacher training since future teachers are powerful agents of change in the lives of young people. Future teachers need to acquire competencies in sustainability to be able to promote meaningful changes in sustainable behaviour. To that end, holistic approaches to facilitate their acquisition need to be developed. The aim of this study is to explore which teaching methodologies are suitable for the development of competencies in sustainability and research in Higher Education (HE). The participants taking part in the study are students in pre-service teacher training. The experimental educational model used for the development of competencies in sustainability and research consists of a methodological sequence of Project-Oriented Learning (POL) and a Cross-disciplinary Workshop on Sustainable Food. This study provides evidence that POL is an excellent methodology for developing competencies in sustainability and facilitates the relationship between sustainability and research competencies.
\end{abstract}

Keywords: sustainability competencies; research competencies; teacher training; Project-Oriented Learning; cross-disciplinary workshop on sustainable food; sustainable food; Higher Education

\section{Introduction}

Considering the Earth continues to speed down an unsustainable path, several educational actors identified the need to create programmes [1,2] to raise citizen awareness and encourage sustainable behaviour. The publication in 2015 of the UN 2030 Agenda includes the 17 Sustainable Development Goals (SDGs) that should be a priority for all governments and citizens until 2030. These 17 SDGs are the reformulation of the Millennium Development Goals, seeking to promote sustainable development (SD) in an integrated manner, as reflected in the preamble of the declaration [3]. The vast majority of environmental issues, in addition to damaging ecosystems, are linked to problems affecting human health and the livelihood of numerous human populations. Scientists agree we are facing a new epoch called the Anthropocene, characterised by global environmental degradation problems of human origin [4]. Political agreements, economic incentives and technological solutions are not enough to address the challenges of SD. To create a fairer, more peaceful and sustainable world, a collective effort is required by all individuals and societies and this is where Education for Sustainable development (ESD) has a crucial role to play, transmitting knowledge, competencies and values [5].

The resolution of the UN General Assembly declaring a Decade of Education for Sustainable Development (2005-2014) emphasised that "education is an indispensable element for achieving 
sustainable development" [6] (p. 1). More recently, the publication by UNESCO: Education for Sustainable Development Goals. Learning Objectives [1] highlighted that education is a key instrument to achieve the SDGs. In the same vein, the former Director-General of UNESCO, Irina Bokova, stated: "A fundamental change is needed in the way we think about education's role in global development because it has a catalytic impact on the well-being of individuals and the future of our planet. [ ... ] Now, more than ever, education has a responsibility to be in gear with 21st century challenges and aspirations and foster the right types of values and skills that will lead to sustainable and inclusive growth, and peaceful living together" [1] (p. 7). Higher education institutions (HEIs) play a key role in the implementation of the 2030 Agenda of the United Nations and developing competencies in sustainability at university level is a way to promote it [1].

Future teachers will not be able to provide education to promote sustainable development if they themselves have not acquired the necessary competencies in sustainability $[7,8]$.

Possessing competencies in sustainability is crucial for future teachers as their influence reaches far beyond the classroom and can contribute to building a more sustainable society [1,9-12]. Not only do teachers have to be knowledgeable and deliver convincing arguments, their behaviour needs to be consistent with what is taught in the classroom. Education to develop sustainability competencies is considered a key element in Education for SDGs [1].

Implementing the SDGs does not only require knowledge creation. A change in teaching methods [1] and in the methodological strategies related to ESD is necessary [13]. This includes learning from real-world problems, anticipating and preparing for future sustainability challenges $[14,15]$, core methodologies, integrative thinking and participation [16].

Since the implementation of the European Higher Education Area (EHEA) in universities, competency-based teaching and learning was introduced [17]. The concept of competency is problematic. According to Lambrechts and Van Petegem "the competence concept has become too elastic and too blurry, due to mixed interpretations and expectations" [18]. This study considers the competency concept as the capacity to integrate knowledge, skills and attitudes in order to perform tasks and solve problems in a given context [19].

In less than two decades, numerous initiatives have been taken to promote competencies in sustainability in HE [20-28]. Teaching based on competencies in sustainability therefore presents a new challenge for university teachers and more particularly for those who teach future teachers $[7,12,27,29]$, as they have to implement suitable teaching strategies for their students to develop competencies in sustainability $[1,2,9,10]$.

The Conference of Rectors of Spanish Universities (CRUE in Spanish) drafted and approved documents proposing core competencies in sustainability [16], which are the ones used in this experimental educational model. The following four cross-curricular competencies for sustainability are proposed for inclusion in HE:

- SUST1. Competency in the critical contextualisation of knowledge through linking social, economic and environmental issues at a local and/or global level;

- $\quad$ SUST2. Competency in the sustainable use of resources and in the prevention of negative impacts on natural and social environments;

- $\quad$ SUST3. Competency to participate in community processes that promote sustainability;

- $\quad$ SUST4. Competency to apply ethical principles related to sustainability values in personal and professional behaviour.

Lambrechts and Van Petegem (2016) show sustainability and research competencies interrelate within a context of competency-based higher education [18]. They developed this key idea, observing interrelations between competencies for SD and research competencies. According to the authors, all lists of core competencies in sustainability contain elements that are relevant within a research context.

Given the need to create holistic approaches to develop sustainability and research competencies in pre-service teacher training, the third year students of the Degree in Primary Education at the 
Universitat Internacional de Catalunya (UIC) in Barcelona were asked to elaborate a research project related to sustainable food.

The preamble of the 2030 Agenda clearly states that the different dimensions of SD must be implemented in an integrated manner [3]. Both the document of the United Nations Conference on Sustainable Development, Rio+20, aimed at universities [30], and the documents developed by UNESCO to implement the SDGs related to education, call for holistic and integrated approaches to $\mathrm{SD}[1,10]$.

By proposing a research project (following the POL methodology) related to sustainable food, the idea was to address SDG 12, which concerns sustainable food consumption. Sustainable food, which is directly related to health and education, enabled working on the social, environmental and economic dimension of sustainability in an integrated manner, dealing with real everyday problems. When presenting the findings of their research to the university community, the students took a leading role in the implementation of an SDG at their university.

In the context of developing competencies in ESD in HE, it is necessary to develop sustainability and research competencies using holistic approaches. ESD requires rethinking learning environments to inspire learners to act for sustainability [5]. To incorporate sustainability competencies and pedagogies promoting research in a participative manner [31], an interactive learning environment is recommended [5]. The POL research methodology is considered ideal to work on competencies in sustainability [32]. Lambrechts and Van Petegem (2016) saw the interrelation between sustainability and research competencies [18].

This study aims to answer the following questions:

1. Is the POL methodology suitable for the development of competencies in sustainability for the students?

2. Does carrying out a research project on sustainable food enable developing Sustainability and Research Competencies together?

\section{Material and Methods}

The materials and methods used to carry out this study are set out below. With respect to materials, two assessment instruments for collecting data are used to conduct the study. Each instrument is the result of previous studies, which are described in this section. Regarding the methodology employed, the pedagogical approaches and methodological scenarios used for the development of sustainability and research competencies, consisting of Project-Oriented Learning (POL) and the Cross-disciplinary Workshop on Sustainable Food, are explained in detail.

\subsection{Participants and Instruments to Collect Data}

The participants taking part in the research project were 23 students of the Degree in Primary Education of the Faculty of Education at the UIC. The average age of the students was 20.5.

Three instruments were used in the research process:

(a) Rubric for assessment of four competencies in sustainability (SUST 1-SUST 4) defined at three levels of competency acquisition. This rubric was developed within the framework of the EDINSOST Project in which researchers from ten Spanish universities took part. A rubric or competency map on sustainability was elaborated, defining each competency at three levels of competency acquisition [33]. For this purpose, a structure based on four competencies related to sustainability was defined: SUST1-SUST4. Each competency was divided into three levels, which were defined using the levels of competency of the simplified Miller pyramid [34]. To make assessment easier, levels "Shows how" and "Does" were joined into one level. Miller (1990) established a hierarchy of competencies in the medical profession (which can also be applied to other professions). From the selection of competencies and the hierarchy of results established by Miller (1990), the study focuses on analysing what the learning outcomes allow us to evaluate. 
It established three levels of acquisition defined by learning outcomes (indicators), based on the standards set by the National Centre for Education Statistics of the United States [35]. The first level (Knows) corresponds to knowledge and refers to learning, the second level (Knows how) corresponds to integration and development in the situation and finally, the third level (Shows how and Does) is related to demonstrating competency in the action and the possibility of transferring this action (Table 1).

(b) Instrument for assessment of four competencies in sustainability and one research competency used by experts in the oral presentation of the students' research projects (Table 2). In this assessment instrument, the five competencies that appear in Table 1 are assessed on a scale of 0 to 2, where $0-0.5=$ lacks command of the competency; $0.5-1$ = poor command (only knows); $1-1.5=$ good command (knows how) and 1.5-2 = very good command (show how and does). To elaborate this tool, the competencies in sustainability approved by the CRUE were adapted to assess the students' acquisition of competencies in their research projects on sustainable food. The correlation between those two kinds of competencies is shown in Table 3.

(c) Instrument for assessment of the competency in sustainability and the research competencies, used by the teachers of didactics of mathematics, science and language, in the written presentation of the students' research projects. In this instrument to collect data, the competency in sustainability and the research competencies that appear in Table 4 are assessed on a scale of 0 to 2, in the same way as in the rubric mentioned earlier. The research competencies analysed correspond to six research competencies put into practice at KH Leuven (based on Vanhoren and Lambrechts, 2009). Table 5 shows the correlation between the research competencies presented by Lambrechts and Van Petegem [18] and the research competencies assessed in the written presentation of the students' research projects in this study. 
Table 1. Competency Map on Sustainability in Education at University level. Elaborated by Albareda et al. (in press) within framework of the EDINSOST project.

\begin{tabular}{|c|c|c|c|c|c|}
\hline \multicolumn{6}{|c|}{ SUST Competency Map of All the Degrees in Education } \\
\hline \multirow{2}{*}{ Related Competencies } & \multirow{2}{*}{ Dimension } & \multirow{2}{*}{ Competency Unit } & \multicolumn{3}{|c|}{ Domain Levels (According to the Simplified Miller Pyramid) } \\
\hline & & & Level 1. KNOWING & Level 2. KNOWING HOW & Level 3. SHOWING \& DOING \\
\hline \multirow{2}{*}{$\begin{array}{l}\text { SUST 1 Critical contextualization } \\
\text { of knowledge establishing } \\
\text { interrelationships between social, } \\
\text { economic and environmental, } \\
\text { logal and/or global problems }\end{array}$} & \multirow[t]{2}{*}{ Holistic } & $\begin{array}{l}\text { 1.1. Understands the functioning of } \\
\text { natural, social and economic systems, } \\
\text { as well as their interrelations and } \\
\text { problems, both at a local and global } \\
\text { level }\end{array}$ & $\begin{array}{l}\text { Knows the functioning of natural, } \\
\text { social and economic systems and the } \\
\text { mutual relations between them }\end{array}$ & $\begin{array}{l}\text { Analyses and understands the } \\
\text { relationship between natural systems } \\
\text { and social and economic systems }\end{array}$ & $\begin{array}{l}\text { Is able to imagine and predict the } \\
\text { impacts the changes produced in } \\
\text { natural systems may cause in } \\
\text { social and economic systems and } \\
\text { among each other }\end{array}$ \\
\hline & & $\begin{array}{l}\text { 1.2. Possesses critical thinking and } \\
\text { creativity, taking advantage of the } \\
\text { different opportunities presented (ICT, } \\
\text { strategic plans, regulations, etc.) in the } \\
\text { planning of a sustainable future }\end{array}$ & $\begin{array}{l}\text { Knows the procedures and resources } \\
\text { to integrate sustainability into } \\
\text { educational projects }\end{array}$ & $\begin{array}{l}\text { Understands and takes advantage of } \\
\text { the opportunities that present } \\
\text { themselves in educational contexts in } \\
\text { order to plan sustainable projects }\end{array}$ & $\begin{array}{l}\text { Provides solutions to educational } \\
\text { projects from a critical and } \\
\text { creative viewpoint with the aim } \\
\text { of planning a sustainable future }\end{array}$ \\
\hline $\begin{array}{l}\text { SUST } 2 \text { Sustainable use of } \\
\text { resources in the prevention of } \\
\text { negative impacts on natural and } \\
\text { social environments }\end{array}$ & Holistic & $\begin{array}{l}\text { 2.1. Designs and develops actions, } \\
\text { making decisions that take into } \\
\text { account the environmental, economic, } \\
\text { social, cultural and educational } \\
\text { impacts so as to improve sustainability }\end{array}$ & $\begin{array}{l}\text { Has basic knowledge of identifying } \\
\text { possible socio-environmental impacts } \\
\text { derived from educational actions }\end{array}$ & $\begin{array}{l}\text { Knows how to develop educational } \\
\text { actions that mitigate negative } \\
\text { socio-environmental impacts }\end{array}$ & $\begin{array}{l}\text { Designs and develops } \\
\text { educational activities in which } \\
\text { negative socio-environmental } \\
\text { impacts are taken into account } \\
\text { and incorporates mitigating } \\
\text { measures }\end{array}$ \\
\hline $\begin{array}{l}\text { SUST } 3 \text { Participation in } \\
\text { community processes that } \\
\text { promote sustainability }\end{array}$ & Holistic & $\begin{array}{l}\text { 3.1. Promotes and participates in } \\
\text { community activities that encourage } \\
\text { sustainability }\end{array}$ & $\begin{array}{l}\text { Recognises himself/ herself as an } \\
\text { integral part of his/ her } \\
\text { surroundings and knows the } \\
\text { community education programmes } \\
\text { that encourage participation and } \\
\text { commitment to socio-environmental } \\
\text { improvement }\end{array}$ & $\begin{array}{l}\text { Is able to interact satisfactorily in } \\
\text { educational community projects, } \\
\text { encouraging participation }\end{array}$ & $\begin{array}{l}\text { Designs and carries out } \\
\text { socio-educational activities in } \\
\text { participatory community } \\
\text { processes that promote } \\
\text { sustainability }\end{array}$ \\
\hline \multirow[t]{2}{*}{$\begin{array}{l}\text { SUST } 4 \text { Application of ethical } \\
\text { principles related to sustainability } \\
\text { values in personal and } \\
\text { professional behaviour }\end{array}$} & \multirow[t]{2}{*}{ Holistic } & $\begin{array}{l}\text { 4.1. Is consistent in actions respecting } \\
\text { and valuing (biological, social and } \\
\text { cultural) diversity and commited to } \\
\text { improving sustainability }\end{array}$ & $\begin{array}{l}\text { Knows the ethical principles of } \\
\text { sustainability and the importance of } \\
\text { respecting diversity in educational } \\
\text { intervention }\end{array}$ & $\begin{array}{l}\text { Understands and integrates the ethical } \\
\text { principles of sustainability in his/ her } \\
\text { actions, considering nature as a good in } \\
\text { intself and transmitting the importance } \\
\text { of education for a change in the } \\
\text { relationship between human beings } \\
\text { and the socio-cultural environment }\end{array}$ & $\begin{array}{l}\text { Is able to design and/ or manage } \\
\text { educational projects taking into } \\
\text { account ecological ethics to } \\
\text { improve quality of life and to } \\
\text { promote the common good }\end{array}$ \\
\hline & & $\begin{array}{l}\text { 4.2. Promotes education in values } \\
\text { oriented to the formation of } \\
\text { responsible, active and democratic } \\
\text { citizens }\end{array}$ & $\begin{array}{l}\text { Takes into account promoting } \\
\text { integral and sustainable human } \\
\text { development as the basic purpose of } \\
\text { the formation of citizenship }\end{array}$ & $\begin{array}{l}\text { Critically analyses and assesses the } \\
\text { consequences his/ her personal and } \\
\text { professional actions may have on the } \\
\text { integral development of students and } \\
\text { on promoting sustainable human } \\
\text { development }\end{array}$ & $\begin{array}{l}\text { Designs and develops } \\
\text { educational intervention } \\
\text { proposals that integrate the } \\
\text { values of sustainability and } \\
\text { which result in justice and the } \\
\text { common good }\end{array}$ \\
\hline
\end{tabular}


Table 2. Instrument for assessment of four competencies in sustainability and one research competency using the levels of competency of the simplified Miller pyramid.

\begin{tabular}{|c|c|c|c|c|}
\hline \multirow{2}{*}{$\begin{array}{l}\text { Sustainable Competencies and } \\
\text { Research Compentency }\end{array}$} & \multirow{2}{*}{$\begin{array}{l}\text { Lacks Command } \\
\text { of the Competency }\end{array}$} & \multicolumn{3}{|c|}{ Level of Acquisition of the Competency According to Miller } \\
\hline & & Knows & Knows How & Show How and Does \\
\hline \multicolumn{5}{|l|}{$\begin{array}{l}\text { SC. 1. They show interrelations between } \\
\text { food and the environment and economic or } \\
\text { social aspects }\end{array}$} \\
\hline \multicolumn{5}{|l|}{$\begin{array}{l}\text { SC. } 2 \text {. They provide a realistic solution or } \\
\text { proposal for the promotion of } \\
\text { sustainable food }\end{array}$} \\
\hline \multicolumn{5}{|l|}{$\begin{array}{l}\text { SC. } 3 \text {. They work cooperatively } \\
\text { and responsibly }\end{array}$} \\
\hline \multicolumn{5}{|l|}{ SC. 4 . They justify the results obtained } \\
\hline $\begin{array}{l}\text { RC. } 5 \text {. They communicate well, both orally } \\
\text { and in writing }\end{array}$ & & & & \\
\hline
\end{tabular}

Table 3. Correlation between the competencies in sustainability approved by the CRUE and the competencies worked on in the research Project on sustainable food.

\begin{tabular}{ll}
\hline $\begin{array}{l}\text { Competencies in Sustainability Approved by the } \\
\text { CRUE 2012 }\end{array}$ & $\begin{array}{l}\text { Sustainability Competencies (SC) Formulated for the Project } \\
\text { on Sustainable Food Starting from the Competencies in } \\
\text { Sustainability Approved by the CRUE 2012 }\end{array}$ \\
\hline $\begin{array}{l}\text { SUST 1-Critical contextualization of knowledge establishing } \\
\text { interrelationships between social, economic and } \\
\text { environmental, local and/or global problems }\end{array}$ & $\begin{array}{l}\text { 1-They show interrelations between food and the environment and } \\
\text { economic or social aspects }\end{array}$ \\
\hline $\begin{array}{l}\text { SUST 2-Sustainable use of resources in the prevention of } \\
\text { negative impacts on natural and social environments }\end{array}$ & $\begin{array}{l}\text { 2-They provide a realistic solution or proposal for the promotion } \\
\text { of sustainable food }\end{array}$ \\
\hline $\begin{array}{l}\text { SUST 3-Participation in community processes that promote } \\
\text { sustainability }\end{array}$ & 3-They work cooperatively and responsibly \\
\hline $\begin{array}{l}\text { SUST 4-Application of ethical principles related to } \\
\text { sustainability values in personal and professional behaviour }\end{array}$ & 4-They justify the results obtained \\
\hline
\end{tabular}


Table 4. Instrument for assessment of the competency in sustainability and the research competencies, used by the teachers of didactics of mathematics, science and language, in the written presentation of the students' research projects.

\begin{tabular}{|c|c|c|c|c|c|c|c|c|c|c|c|c|c|c|c|c|c|c|c|c|}
\hline \multirow[b]{2}{*}{$\begin{array}{c}\text { Competences of } \\
\text { Sustainability Evaluated } \\
\text { by Teacher for the Faculty }\end{array}$} & \multicolumn{4}{|c|}{ Sustainability Competency } & \multicolumn{16}{|c|}{ Research Competency } \\
\hline & \multicolumn{4}{|c|}{$\begin{array}{l}\text { They Show Interrelations } \\
\text { between Food and } \\
\text { Environmental, Economic or } \\
\text { Social Aspects }\end{array}$} & \multicolumn{4}{|c|}{$\begin{array}{l}\text { The Theoretical Framework } \\
\text { or Introduction and the } \\
\text { Objectives Are Well } \\
\text { Elaborated. Correct Research } \\
\text { Methodology }\end{array}$} & \multicolumn{4}{|c|}{$\begin{array}{l}\text { They Justify the Results } \\
\text { Obtained and Use Charts in } \\
\text { an Appropriate Way }\end{array}$} & \multicolumn{4}{|c|}{$\begin{array}{l}\text { They Communicate } \\
\text { Correctly in Written Form }\end{array}$} & \multicolumn{4}{|c|}{$\begin{array}{c}\text { Correct Bibliography. Good } \\
\text { Quotations. They Take Care } \\
\text { of the Formal Aspects of the } \\
\text { Figures, Margins, etc. }\end{array}$} \\
\hline Maximum Score & \multicolumn{4}{|c|}{$0-2$} & \multicolumn{4}{|c|}{$0-2$} & \multicolumn{4}{|c|}{$0-2$} & \multicolumn{4}{|c|}{$0-2$} & \multicolumn{4}{|c|}{$0-2$} \\
\hline 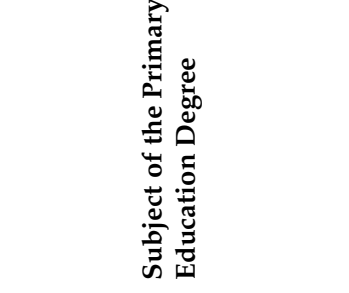 & 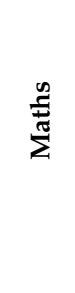 & 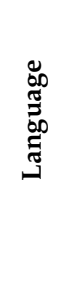 & $\underset{\mathscr{E}}{\mathscr{E}}$ & 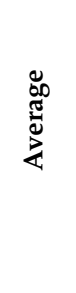 & 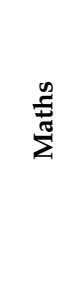 & 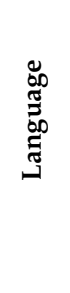 & 苞 & 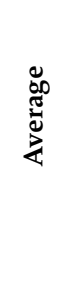 & 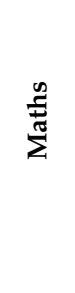 & 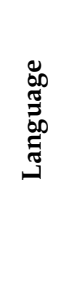 & 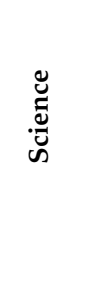 & 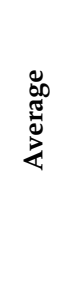 & $\sum_{\sum}^{\infty}$ & 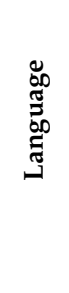 & $\stackrel{\mathscr{E}}{\tilde{D}}_{\mathscr{E}}$ & 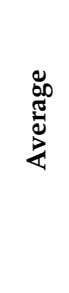 & 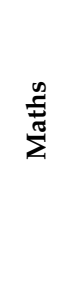 & 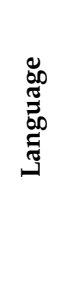 & $\stackrel{\mathscr{E}}{\tilde{D}}_{\mathscr{E}}$ & 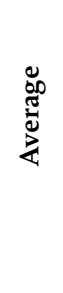 \\
\hline $\begin{array}{l}\text { Project } 1 \\
\text { Project } 2 \\
\text { Project } 3 \\
\text { Project } 4 \\
\text { Project } 5 \\
\text { Project } 6\end{array}$ & & & & & & & & & & & & & & & & & & & & \\
\hline
\end{tabular}


Table 5. Correlation between the research competencies presented by Lambrechts and Van Petegem and the research competencies in this study.

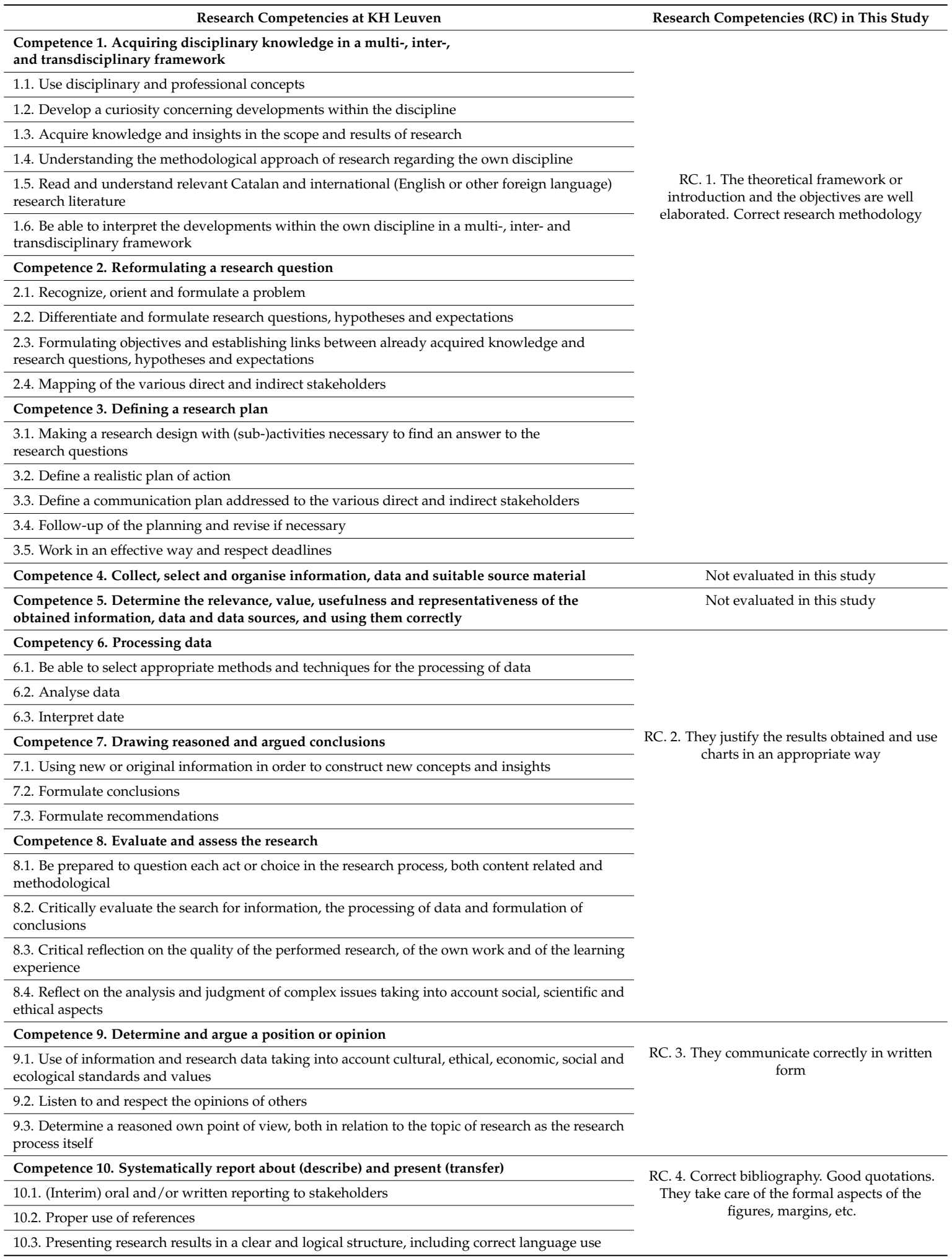

\subsection{Pedagogical Approaches to Develop Sustainability and Research Competencies}

Working on competencies in sustainability and research competencies, together with the educational need to implement the SDGs in universities, led the authors of this article to develop a 
holistic and integrated approach using methodologies that enable addressing the complexity of current sustainability issues [36].

In accordance with UNECE in the publication "Empowering educators for a sustainable future" [10], holistic approaches were sought to develop sustainability competencies. Pedagogical approaches need to facilitate the development of competencies and the methodologies applied must therefore be integrating. They cannot simply be limited to the transmission of knowledge. They have to engage the students in real-world activities achieving active participation.

Recent studies on sustainability education show that effective approaches tended to focus on the comprehensive view of a sustainability problem and its possible solutions [31,37], for it enables students to put their ideas forward, integrate their knowledge, work together, make decisions and, on the whole, use their competencies $[7,38]$. Using those references as a starting point, two pedagogical approaches were selected and developed: Project-Oriented Learning (POL) and a Cross-disciplinary Workshop on Sustainable Food.

In small groups, the students had to develop a research project on a real problem related to the consumption aspect of SDG 12 in the field of sustainable food as a method to develop competencies in sustainability and in research. They worked on the projects in the subjects of Didactics of Mathematics (the weight of the project was $20 \%$ of the total mark of the subject), Didactics of Language and Literature $(10 \%)$ and Didactics of Experimental Sciences (20\%).

The students conducted the research projects on sustainable food for a period of two and a half months, using the POL methodology. All the research projects were presented to the university community on the day of the Cross-Disciplinary Workshop on Sustainability. Twenty experts in the subject, including lecturers from the university itself, lecturers from four other universities and experts from the Sustainability Department of Barcelona's City Council participated in the evaluation of the projects. All the evaluators had the same data collecting instrument for the evaluation of the students and they valued the following competencies: (1) They show interrelations between food and environmental, economic or social aspects; (2) They provide a realistic solution or proposal for the promotion of sustainable food; (3) They work cooperatively and responsibly; (4) They justify the results obtained and (5) They communicate well, both orally and in writing.

The integrated approaches of POL and the Cross-disciplinary Workshop on Sustainable Food (Figure 1), enabled working on and assessing sustainability and research competencies together.
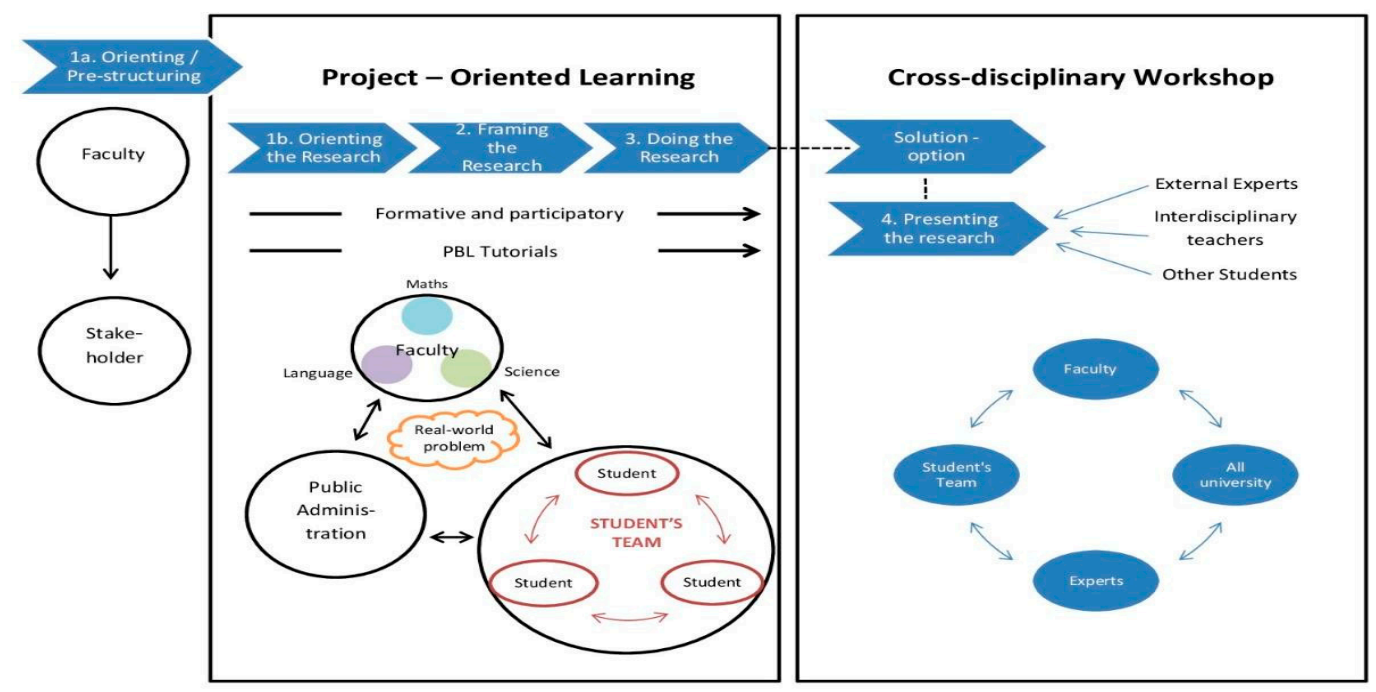

Figure 1. Methodological scenarios for the development of sustainability and research competencies Source: Own work, inspired by Brundiers \& Wiek, 2013 [32]. 


\subsubsection{Project-Oriented Learning (POL)}

POL is an instructional methodology for active learning, in which students work together in small groups researching and solving real-world problems. Through POL, a shared co-creation process was performed in a learning environment that fostered research. This methodology is mentioned in the literature as an ideal tool to develop competencies in sustainability [39-41]. A recent study shows that POL is more effective than other methodologies to work in support of integrated approaches to sustainability [32].

Using POL, several groups of three to four students engaged in a research project related to sustainable food, which they presented to the rest of the university community at the Cross-disciplinary Workshop on Sustainable Food. After more than two months of research and interactive reflection, the students presented their research findings using a scientific poster or an interactive workshop to the rest of the university community. It encouraged addressing sustainable food in a cross-disciplinary manner. After presenting their projects, they were evaluated by a group of experts.

\subsubsection{Cross-Disciplinary Workshop on Sustainable Food}

A Cross-disciplinary Workshop on Sustainability is organised by the Sustainability Office of the Universitat Internacional de Catalunya every year. Its aim is for the university community to become aware of the importance of sustainability as an essential part of both education and preparation for the challenges of tomorrow. It encourages students and teachers to become part of the driving force for change towards a sustainable world. Teachers and students from different degree programmes can reflect on and share research projects in a common space. The topics addressed in the workshop during the past few years were related to one of the SDGs.

Information is provided through conferences, round tables, scientific workshops and posters to encourage reflection and a change of habits directed towards more sustainable behaviour. All the students can elaborate research projects related to the subjects addressed in the workshop and present their research results in the form of a workshop or scientific poster. The Workshop on Sustainability of academic year 2017-2018 was about sustainable food, which is related to SDG 12: sustainable consumption. Sustainable Food is also connected to SDG 3: good health and wellbeing and SDG 4: Quality Education. The concept of Sustainable Food enables working on and developing sustainable competencies using holistic approaches in a cross-disciplinary manner.

The objective of the ninth edition of the Cross-Disciplinary Workshop on Sustainability was to look at sustainable food and analyse the connection between healthy eating and protecting the planet.

Through student presentations and by listening to and talking to experts from different disciplines, issues such as: 'How does food waste relate to social justice? How is it that in 2017 there were 795 million people suffering from severe malnutrition? Is ecological agriculture sustainable? What is the relation between diet and climate change?' were explored.

The projects presented were the following: Does being vegetarian help to reduce the ecological footprint? The overexploitation of fisheries; What if changing our diet saved the planet? Study on how the consumption of meat affects the planet. The ecological footprint of school dining rooms; Abandon ultra-processed foods: improve your health and sustainability and Cheap gold: palm oil and its impacts.

\section{Results and Analysis}

\section{Results of the Evaluation of Sustainability and Research Competencies}

The experts' evaluation results of the students' competencies in sustainability and the research competency regarding the activity of the Cross-disciplinary Workshop on Sustainable Food were highly positive. According to the global results shown in Table 6, all the groups developed competencies in sustainability and the research competency. The overall marks of the research projects presented by the students oscillate between 7.13 and 9.88 out of 10 . According to the assessment performed by the experts, a good overall level of acquisition of the different competencies is observed. 
Table 6. Sustainability Competencies (SC) and the Research Competency (RC) evaluated by external experts.

\begin{tabular}{|c|c|c|c|c|c|}
\hline Maximum Score & $0-2$ & $0-2$ & $0-2$ & $0-2$ & $0-2$ \\
\hline $\begin{array}{l}\text { Sustainability Competencies and } \\
\text { Research Competency (RC) } \\
\text { Evaluated by External Experts }\end{array}$ & $\begin{array}{l}\text { SC 1. Interrelations between } \\
\text { Food and Environ-Economic- } \\
\text { Social Aspects }\end{array}$ & $\begin{array}{c}\text { SC 2. Provide Realistic } \\
\text { Solutions for the Promotion } \\
\text { of Sustainable Food }\end{array}$ & $\begin{array}{c}\text { SC 3. Work } \\
\text { Cooperatively and } \\
\text { Responsibly }\end{array}$ & SC 4. Justify the Results & $\begin{array}{l}\text { RC. They Communicate Well, } \\
\text { Both Orally and in Writing }\end{array}$ \\
\hline Title of the Project & \multicolumn{4}{|c|}{ Sustainability Competencies } & RC \\
\hline $\begin{array}{l}\text { 1. Does being vegetarian help to } \\
\text { reduce the ecological footprint? }\end{array}$ & 1.58 & 1.33 & 1.80 & 1.33 & 1.33 \\
\hline 2. The overexploitation of fisheries & 1.58 & 1.47 & 1.42 & 1.42 & 1.25 \\
\hline $\begin{array}{l}\text { 3. What if changing our diet saved the } \\
\text { planet? Study on how the consumption } \\
\text { of meat affects the planet }\end{array}$ & 2.00 & 1.92 & 2.00 & 2.00 & 1.75 \\
\hline $\begin{array}{l}\text { 4. The ecological footprint of school } \\
\text { dining rooms }\end{array}$ & 1.81 & 1.75 & 1.88 & 1.69 & 1.81 \\
\hline $\begin{array}{l}\text { 5. Abandon ultra-processed foods: } \\
\text { improve your health and sustainability }\end{array}$ & 1.75 & 1.92 & 1.92 & 2.00 & 2.00 \\
\hline 6. Cheap gold: palm oil and its impacts & 2.00 & 1.94 & 1.94 & 2.00 & 2.00 \\
\hline
\end{tabular}


The results of each competency may be analysed separately. Sustainability Competency: (1) They show interrelations between food and environmental, economic or social aspects (SUST 1, adapted to the project on sustainable food) is the competency that obtains the best results. All the groups attained the highest level of competency acquisition (Shows how and Does), reaching values between 1.58 and 2 . The results may be due to the fact that, from the very beginning, students were encouraged to work on sustainability in an integrated manner connecting environmental, social and economic aspects. The questions initially raised by the students and which gave rise to the research project developed through POL linked two or more dimensions of sustainability. For instance, the group conducting research on palm oil wanted to know about the social and environmental impacts the current consumption of palm oil is causing and which everyday consumer products (detergent, toothpaste, biscuits, etc.) contain palm oil so as to promote alternatives that encourage more sustainable consumption.

The starting point of all the research projects was a real-word problem, the root cause of which was analysed.

Sustainability Competency: (2) They provide a realistic solution or proposal for the promotion of sustainable food is an adaptation of SUST 2. The evaluation results of this competency (Figure 2, in orange) show two groups attained the second level of competency acquisition (between 1.33 and 1.47) and four groups reached the highest level of competency acquisition (between 1.75 and 1.92). Two groups remained at the second level in this competency that strives to find realistic solutions to food problems. In this case, it means the students detected the problem-for instance, in the project of "overexploitation of fisheries" - but they did not present any workable solutions. They analysed what overfishing consisted in and studied the fish consumption habits of the university population, but failed to promote solutions related to eating for the problem of overfishing. In the conclusions of their project the students claimed that: "the overexploitation of fisheries is a growing phenomenon in society. The demand for fish has increased over time and it has been demonstrated that our consumption habits do not help redirect the situation." They condemned the problem, but failed to present viable solutions.

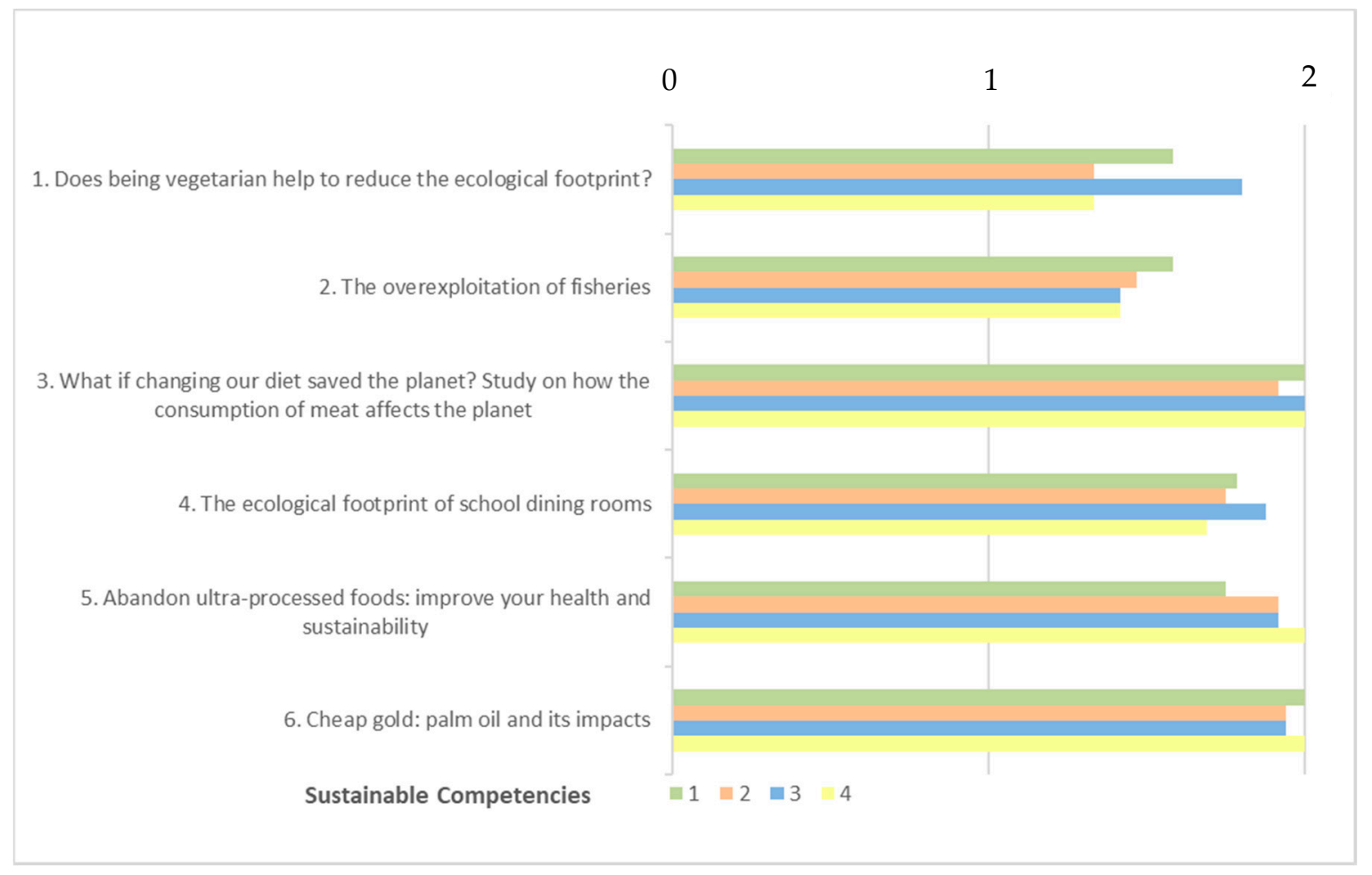

Figure 2. Evaluation results of Sustainability Competencies. 
The evaluation results of Sustainability Competency: (3) They work cooperatively and responsibly, which correspond to SUST 3, show all the groups except one attained the highest level of competency acquisition. During the work performed through POL for over two months and throughout the research presentations, the students gave to the university community, it was observed that the members of the different groups shared the work equally and they worked well together. The intention of using POL was to promote teamwork, which requires dialogue and consensus in addition to the distribution of tasks. In view of the results, it may be inferred that the POL methodology is ideal for teamwork.

Figure 2 (in yellow) shows the evaluation results of Sustainability Competency: (4) They justify the results obtained, related to (though not exactly the same) SUST 4: Competency to apply ethical principles related to sustainability values in personal and professional behaviour. In the oral presentation of the projects this competency was considered a competency in sustainability and in the written presentation of the projects as a research competency. We believe it may be analysed from both perspectives and one of the objectives in this study is to show their correlation.

By using POL, the students were encouraged to act ethically in their research and presentation of their findings. They were evaluated to see whether they were the real authors of the work presented (by checking for plagiarism) and whether the entire research process was rigorous. According to the results obtained, four groups reached a very good level and two groups attained a good level. The reason why not all groups obtained a very good level is not due to plagiarism, but to a lack of training in research and to not being able to sufficiently justify the findings obtained. These results show further training in research is necessary for university students.

The results of evaluating Research Competency: (5) They communicate well, both orally and in writing are very similar to the previous competency because they are related to each other. When research is performed rigorously and justified conclusions are presented, it is common to communicate well, both orally and in writing.

All these competencies were also assessed by the teachers of third year subjects in the degree of Primary Education, in which the research projects on sustainable food were developed to work on competencies in sustainability and the research competencies. At the end of the entire process, each group of students had to present written work (written communication) that had to include all the sections of a scientific paper: title, abstract of the project (maximum 200 words); theoretical framework or introduction; objectives of the research project; research method; results and discussion; conclusions and bibliographic references (in accordance with the 6th edition of the APA Publication Manual). The length of the project, without including bibliographic references, had to be between 10 pages and 15 pages. The different teachers evaluated this written work separately using the assessment instrument described in Table 7 below. 
Table 7. Sustainability Competency and Research Competencies evaluated by teachers of the faculty.

\begin{tabular}{|c|c|c|c|c|c|c|c|c|c|c|c|c|c|c|c|c|c|c|c|c|c|c|c|}
\hline \multirow{2}{*}{$\begin{array}{c}\text { Competences of } \\
\text { Sustainability Evaluated } \\
\text { by Teacher fo the Faculty }\end{array}$} & \multirow{2}{*}{\multicolumn{4}{|c|}{$\begin{array}{l}\text { Sustainability Competency } \\
\text { They Show Interrelations } \\
\text { between Food and } \\
\text { Environmental, Economic or } \\
\text { Social Aspects }\end{array}$}} & \multicolumn{16}{|c|}{ Research Competency } & \multirow{3}{*}{ 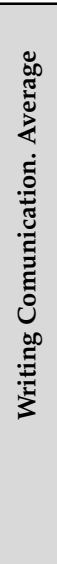 } & \multirow{3}{*}{ 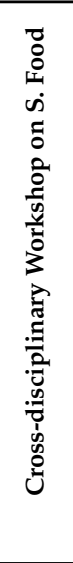 } & \multirow{3}{*}{ 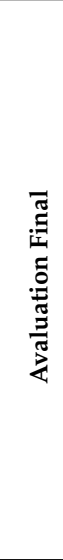 } \\
\hline & & & & & \multicolumn{4}{|c|}{$\begin{array}{l}\text { The Theoretical } \\
\text { Framework or } \\
\text { Introduction and the } \\
\text { Objectives Are Well } \\
\text { Elaborated. Correct } \\
\text { Research Methodology } \\
0-2\end{array}$} & \multicolumn{4}{|c|}{$\begin{array}{l}\text { They Justify the Results } \\
\text { Obtained and Use Charts } \\
\text { in an Appropriate Way }\end{array}$} & \multicolumn{4}{|c|}{$\begin{array}{c}\text { They Communicate } \\
\text { Correctly in Written } \\
\text { Form }\end{array}$} & \multicolumn{4}{|c|}{$\begin{array}{l}\text { Correct Bibliography. } \\
\text { Good Quotations. They } \\
\text { Take Care of the Formal } \\
\text { Aspects of the Figures, } \\
\text { Margins, etc. }\end{array}$} & & & \\
\hline 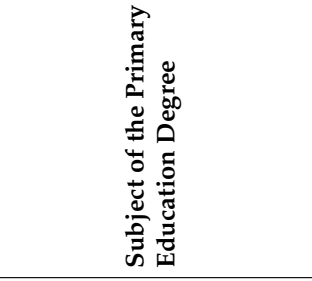 & 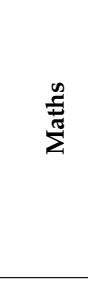 & 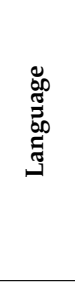 & 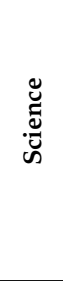 & 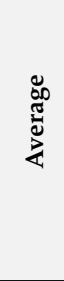 & 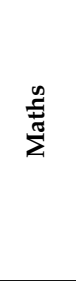 & 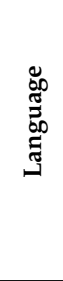 & 苞 & 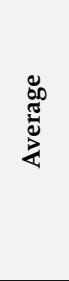 & $\sum_{\substack{\tilde{E} \\
\Sigma}}^{n}$ & 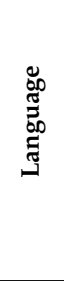 & 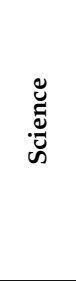 & 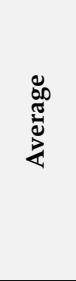 & 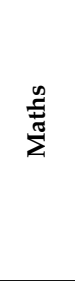 & 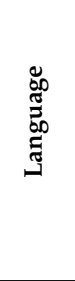 & $\stackrel{\mathscr{E}}{\mathscr{E}}$ & 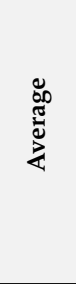 & 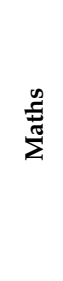 & 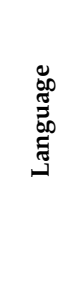 & 节 & 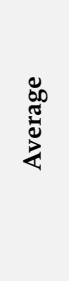 & & & \\
\hline $\begin{array}{l}\text { 1. Does being vegetarian } \\
\text { help to reduce the } \\
\text { ecological footprint? }\end{array}$ & 1.50 & 1.50 & 1.50 & 1.50 & 1.00 & 1.50 & 1.50 & 1.33 & 0.75 & 1.00 & 1.00 & 0.92 & 0.75 & 2.00 & 1.00 & 1.25 & 0.50 & 1.00 & 1.00 & 0.83 & 5.8 & 7.38 & 6.61 \\
\hline $\begin{array}{l}\text { 2. The overexploitation of } \\
\text { fisheries }\end{array}$ & 1.75 & 1.50 & 1.50 & 1.58 & 1.50 & 1.00 & 1.00 & 1.17 & 1.00 & 1.00 & 1.00 & 1.00 & 1.50 & 1.75 & 1.00 & 1.42 & 1.75 & 1.50 & 0.50 & 1.25 & 6.4 & 7.13 & 6.77 \\
\hline $\begin{array}{l}\text { 3. What if changing our } \\
\text { diet saved the planet? } \\
\text { Study on how the } \\
\text { consumption of meat } \\
\text { affects the planet }\end{array}$ & 2.00 & 2.00 & 2.00 & 2.00 & 2.00 & 2.00 & 2.00 & 2.00 & 1.75 & 2.00 & 2.00 & 1.92 & 2.00 & 2.00 & 1.20 & 1.73 & 2.00 & 1.75 & 1.20 & 1.65 & 9.3 & 9.67 & 9.49 \\
\hline $\begin{array}{l}\text { 4. The ecological footprint } \\
\text { of school dining rooms }\end{array}$ & 2.00 & 2.00 & 2.00 & 2.00 & 2.00 & 2.00 & 2.00 & 2.00 & 1.50 & 1.50 & 1.50 & 1.50 & 1.75 & 1.75 & 1.50 & 1.67 & 0.50 & 1.00 & 1.00 & 0.83 & 8 & 8.94 & 8.47 \\
\hline $\begin{array}{c}\text { 5. Abandon } \\
\text { ultra-processed foods: } \\
\text { improve your health and } \\
\text { sustainability }\end{array}$ & 2.00 & 2.00 & 2.00 & 2.00 & 1.50 & 2.00 & 2.00 & 1.83 & 1.50 & 2.00 & 2.00 & 1.83 & 1.50 & 2.00 & 1.50 & 1.67 & 1.50 & 1.75 & 1.50 & 1.58 & 8.9 & 9.58 & 9.25 \\
\hline $\begin{array}{l}\text { 6. Cheap gold: palm oil } \\
\text { and its impacts }\end{array}$ & 2.00 & 2.00 & 2.00 & 2.00 & 1.50 & 2.00 & 2.00 & 1.83 & 2.00 & 2.00 & 2.00 & 2.00 & 2.00 & 2.00 & 1.20 & 1.73 & 1.75 & 1.75 & 1.25 & 1.58 & 9.2 & 9.88 & 9.52 \\
\hline
\end{tabular}


This instrument allowed assessing competency in sustainability (SC. 1) and the research competencies: The theoretical framework or introduction and the objectives are well elaborated; Correct research methodology; They justify the results obtained and use charts in an appropriate way; They communicate correctly in written form and Correct bibliography. Good quotations. They take care of the formal aspects of the figures, margins, etc.

As shown in Table 7, the overall results of the written projects assessed by the teachers of the subjects are all slightly inferior to the same projects presented orally the day of the Cross-disciplinary Workshop on Sustainability assessed by the external experts. This difference in overall results is due to the fact that the competencies evaluated were not the same and they did not have the same weight. In the Cross-disciplinary Workshop on Sustainability, the four competencies in sustainability weighed $80 \%$, while the weight of the research competency was $20 \%$. In the assessment of the written projects, the weight of the competencies was inverted. The competency in sustainability was worth $20 \%$ and the research competency, assessed by means of four indicators, was worth $80 \%$.

The results of these two kinds of competencies may be analysed separately. When the teachers of the subjects assessed the competency in sustainability, the results were slightly superior to the assessment performed by the external experts (Table 7, first column and Table 6, first column). Despite the fact that when the external experts evaluated the different competencies on sustainability, Sustainability Competency: 1) They show interrelations between food and environmental, economic or social aspects, obtained the best results. The results show that when the students are assessed on a more continuous basis (having more time to prepare and gathering more information), they attain a higher command of the competency. When assessed by the teachers of the subject, all the students obtained an excellent level competency in sustainability, and four groups obtained the highest possible score.

With respect to the assessment results of the research competencies on behalf of the teachers of the subjects (Table 7), it was observed that three groups of students attained a good command (Knows how) and the other three groups a very good command or excellent level (Shows how and Does), without any group achieving the highest possible score.

The fact that the marks of the written work are slightly lower than those of the oral presentations given at the Cross-disciplinary Workshop may be due to a number of reasons. It is obvious that a project defended in 15 min may not be assessed in the same manner as a 10-15-page written research project that took the students two and a half months to elaborate and complete. The teachers who evaluated the written work carried out a follow-up of the students during that period of time. Assessing the oral presentations was fast, while correcting the written projects took more time and was much more thorough. As mentioned earlier, the weight of the competencies in sustainability and the research competency was inverted in the two assessments performed.

To respond to objective 2, an analysis was carried out regarding whether a correlation exists between the level of acquisition of the sustainability competency and the level of acquisition of the research competencies in the same research projects (Table 8). 
Table 8. Relation between Sustainability competencies and Research competencies.

\begin{tabular}{|c|c|c|c|c|}
\hline Relation with Key Sustainability Competencies & SC. 1 & SC. 2 & SC. 3 & SC. 4 \\
\hline \multicolumn{5}{|l|}{ Research Competencies } \\
\hline Results (Levels of Competency Acquisition) & $1-2$ & $1-2$ & $1-2$ & $1-2$ \\
\hline $\begin{array}{l}\text { RC } 1 \text { The theoretical framework or introduction and the objecties } \\
\text { are well elaborated. Correct research methodology }\end{array}$ & $100 \%$ & $100 \%$ & $100 \%$ & $100 \%$ \\
\hline $\begin{array}{l}\text { RC } 2 \text { They justify the results obtained and use charts in an } \\
\text { appropiate way }\end{array}$ & $100 \%$ & $100 \%$ & $100 \%$ & $100 \%$ \\
\hline RC 3 They communicate correctly in written form & $100 \%$ & $100 \%$ & $100 \%$ & $100 \%$ \\
\hline $\begin{array}{l}\text { RC } 4 \text { Correct bibliography. Good quotations. They take care of the } \\
\text { formal aspects of the figures, margins, etc. }\end{array}$ & $75 \%$ & $75 \%$ & $75 \%$ & $75 \%$ \\
\hline
\end{tabular}

The students obtained high levels of competency acquisition (Knows how or Show how and Does) in the research competencies RC. 1, RC. 2, RC. 3 and RC. 4, like in SC. 1, SC. 2, SC. 3 and SC. 4 , thus showing a correlation between the levels of acquisition of both sustainability and research competencies. In RC. 4 , a correlation of $75 \%$ is observed with the competencies in sustainability.

\section{Discussion}

In view of the results, it may be said that the objectives this study aimed to reach through the experimental educational model used have been achieved. Two research questions were posed: (1) Is the POL methodology suitable for the development of competencies in sustainability for the students? and (2) Does carrying out a research project on sustainable food enable developing Sustainability and Research Competencies together?

In this study, a sequence of two methodological scenarios, POL and the Cross-disciplinary Workshop (Figure 1) was used as a tool to develop sustainability $[7,29]$ and research competencies. If the methods used had merely been expositive, based solely on the transmission of knowledge, it would not have been possible to develop competencies in sustainability $[14,36]$, let alone attaining a very good command of those competencies [34].

POL, the Cross-disciplinary Workshop and the presentation of the written project enabled developing Sustainability Competency 1 : They show interrelations between food and environmental, economic or social aspects. In accordance with [1,3], sustainability needs to be addressed in an integrating manner, which is reflected in the formulation of this competency. This educational model shows understanding this integrated vision of sustainability is possible when addressing real-world problems [42] that need to be solved. If students are not encouraged to think and act, it is hard for them to interrelate environmental, economic and social aspects and to identify the impact of their daily actions [20].

As POL is a methodology that focuses on students working in small groups trying to solve real problems [31], it facilitated the development of Sustainable Competency 2: They provide a realistic solution or proposal for the promotion of sustainable food. It has also contributed to a "holistic approach to envisioning change and thereby achieving transformation" [10] (p. 6).

The different stages of the methodological sequence (Figure 1), as they are active pedagogical approaches [5,32], also contributed to the development of competencies 3 and 4: "work cooperatively and responsibly" and "justify the results obtained". It is confirmed that, for individuals to understand complex world problems, they need to collaborate with each other [39].

Considering the results of this study and in accordance with [32,39-41], it may be said that POL is a particularly appropriate methodology to develop competencies in sustainability. The first objective of this study has therefore been accomplished. It has enabled training students in the research of sustainable development [43]. According to Brundiers and Wiek (2013) [31], POL offers 
an innovative approach to partnerships between the university and external organisations. In our experimental educational programme, the students interacted with external stakeholders and with public administration employees from the Sustainability Department in Barcelona's City Council (Figure 2). It enables working on knowledge, methodologies and values in an integrated manner, thus developing competencies. Carrying out a research project through POL provided an ideal scenario for the students to develop research competencies at the same time.

As the competencies were difficult to measure and assess [21], this study provided instruments to facilitate the assessment of competencies in both sustainability and research.

Furthermore, as stated in the second question, this study was intended to analyse whether a positive correlation exists between acquiring competencies in sustainability and in research. The results in Table 8 show that by analysing the correlation between the competencies in sustainability and in research, in twelve cases the students attain the same level of acquisition of competencies, ranging from level 1 (knows how) to level 2 (show how and does). In four cases (correlation between RC. 4 and the four competencies in sustainability), a correlation of $75 \%$ is observed. This may be due to the presence of the basic conditions Lambrechts and Van Petegem suggest so that "Research competences and research-based learning methods could contribute to the acquisition of key competences for $\mathrm{SD}^{\prime \prime}$ [18], p. 17. On the one hand, the research conducted on sustainable food was carried out in a cross-disciplinary manner, joining students and teachers from different degree programmes both inside and outside the university. Cross-disciplinary approaches in collaboration with experts external to the university (in the Cross-disciplinary Workshop) enable the simultaneous development of competencies in sustainability and in research. On the other hand, as the aforementioned authors claim, ethical behaviour is inherent to the concept of SD, which was assessed as SC. 4 (see Table 3) in this study.

POL, the presentation and assessment of the students' research projects by means of the Cross-disciplinary Workshop enabled the empowerment of students to be leaders in the implementation of the SDGs in the university. The Cross-disciplinary Workshop was used as a tool to address SDG 12 which regards sustainable consumption. The report "Getting started with the SDGs in universities: A guide for universities, higher education institutions, and the academic sector" [43], recommends universities to hold a half to full day "Cross-university SDG workshop" to work on a particular aspect of sustainability within the university community [43]. This recommendation was put into practice at the Cross-disciplinary workshop on Sustainable Food. The students took centre stage when defending their research projects to external experts, teachers from other faculties and students from different degree programmes, thus driving positive change within the university context [10]. The Cross-disciplinary Workshop on Sustainable Food provided the students with the necessary knowledge, skills and motivation to understand and address SDG 12 with regard to food. It empowered and mobilised young people, future teachers in this case. The university's public engagement and participation in addressing SDG 12 are thus strengthened [43].

The Cross-disciplinary Workshop on Sustainable Food, in addition to being a tool to develop and assess students' competencies in sustainability using holistic and integrated approaches [16,38], has enabled working on sustainability in a cross-curricular manner in the university [1], empowering youth in achieving sustainable food consumption (SDG 12).

\section{Conclusions and Outlook}

The scientific value of this article lies in the provision of several examples of POL approaches and the Cross-disciplinary Workshop on Sustainability. It is demonstrated they are appropriate tools for developing sustainability competencies and research competencies in pre-service teacher training. This paper allows other educators to replicate these approaches in other contexts.

The analysis of the results obtained in the assessment of the competencies revealed the students acquired the necessary competencies. A practical case of integrating sustainability into the curriculum from a holistic viewpoint was also shown. 
It has been shown how POL is an appropriate tool for teaching and learning in an interactive learner-centred manner, enabling exploratory, action-oriented and transformative learning [43]. It is confirmed that POL enables the favourable development of competencies in sustainability and research.

This study has also shown that the Cross-disciplinary Workshop on Sustainability is an opportunity to enable empowerment and mobilization of students in the implementation of the SDGs in the university.

Author Contributions: Conceptualization, S.A.-T., S.V.-R., M.P.-V. and M.F.-M.; Methodology, S.A.-T. and M.F.-M.; Validation, S.A.-T. and M.F.-M.; Formal Analysis, S.A.-T. and M.F.-M.; Investigation, S.A.-T. and M.F.-M.; Resources, S.A.-T., S.V.-R., M.P.-V. and M.F.-M.; Data Curation, S.A.-T. and M.F.-M.; Writing-Original Draft Preparation, S.A.-T.; Writing-Review \& Editing, M.F.-M. and M.P.-V.; Visualization, S.A.-T.; Project Administration, S.A.-T.; Funding Acquisition, S.A.-T., M.F.-M., Pujol-Valls and S.V.-R.

Funding: This research was funded by the government of Catalonia in the call for the ARMIF 2015 project "Global plan of integrating mathematical, scientific and linguistic competencies in pre-service teacher training" [Ref. 2015 ARMIF 00044] and the EDINSOST Project "Education and Social Innovation for Sustainability. Training at Spanish universities of professionals as agents of change to face the challenges of society", funded by the "R\&D State programme oriented towards the challenges facing society" of the Spanish Ministry of Economy and Finance [Ref. EDU 2015-65574-R].

Acknowledgments: We would like to thank to Ann Swinnen for the feedback and comments and also to three anonymous reviewers for helpful comments on an earlier version of this article. The authors gratefully acknowledge the support of the Integral Sustainability and Education (SEI) Research Group of the Universitat Internacional de Catalunya (2017 SGR 119).

Conflicts of Interest: The authors declare no conflict of interest.

\section{References}

1. UNESCO. Education for Sustainable Development Goals. Learning Objectives; UNESCO: Paris, France, 2017. Available online: http:/ / unesdoc.unesco.org/images/0024/002474/247444e.pdf (accessed on 4 June 2018).

2. United Nations Economic Commission for Europe (UNECE). Ten Years of the UNECE STRATEGY for Education for Sustainable Development; United Nations Economic Commission for Europe (UNECE): New York, NY, USA; Geneva, Switzerland, 2016.

3. UNITED NATIONS. Transforming Our World: The 2030 Agenda for Sustainable Development. Resolution adopted by the General Assembly on 25 September 2015. Available online: http://www.un.org/en/ development/desa/population/migration/generalassembly/docs/globalcompact/A_RES_70_1_E.pdf (accessed on 4 June 2018).

4. Duarte, C.M. Cambio Global. Impacto de la Actividad Humana Sobre el Planeta Tierra; CSIC: Madrid, Spain, 2009.

5. UNESCO. Roadmap for implementing the Global Action Programme on Education for Sustainable Development. 2014. Available online: http://unesdoc.unesco.org/images/0023/002305/230514e.pdf (accessed on 6 July 2018).

6. UNITED NATIONS. 57/254. United Nations Decade of Education for Sustainable Development. Resolution Adopted by the General Assembly UNESCO, General Assembly. 2002. Available online: http://www.undocuments.net/a57r254.htm (accessed on 6 June 2018).

7. Vega-Marcote, P.; Varela-Losada, M.; Álvarez-Suárez, P. Evaluation of an Educational Model Based on the Development of Sustainable Competencies in Basic Teacher Training in Spain. Sustainability 2015, 7, 2603-2622. [CrossRef]

8. Ull Solís, M.Á. Competencias para la sostenibilidad y competencias en educación para la sostenibilidad en la educación superior. Uni-Pluri/Versidad 2015, 14, 46-58.

9. United Nations Economic Commission for Europe (UNECE). Strategy for Education for Sustainable Development. Learning for the Future: Competences in Education for Sustainable Development 2011. Available online: https://www.unece.org/fileadmin/DAM/env/esd/ESD_Publications/Competences_ Publication.pdf (accessed on 6 June 2018).

10. United Nations Economic Commission for Europe (UNECE). Empowering Educators for a Sustainable Future. Tools for Policy and Practice Workshops on Competences in Education for Sustainable Development; United Nations Economic Commission for Europe (UNECE): Geneva, Switzerland, 2013. 
11. Cebrián, G.; Junyent, M. Competencies in education for sustainable development: Exploring the student teachers' views. Sustainability 2015, 7, 2768-2786. [CrossRef]

12. García, M.R.; Junyent, M. How to assess professional competencies in Education for Sustainability? An approach from a perspective of complexity. Int. J. Sustain. High. Educ. 2016, 18, 772-797. [CrossRef]

13. Albareda-Tiana, S.; Vidal-Raméntol, S.; Fernández-Morilla, M. Implementing the Sustainable Development Goals at University level. Int. J. Sustain. High. Educ. 2018, 19, 473-497. [CrossRef]

14. Ryan, A.; Tilbury, D. Flexible Pedagogies: New Ideas. Flexible Pedagogies: Preparing for the Future; Higher Education Academy: New York, NY, USA, 2013.

15. Wiek, A.; Withycombe, L.; Redman, C.L. Key competencies in sustainability: A reference framework for academic program development. Sustain. Sci. 2011, 6, 203-218. [CrossRef]

16. UNESCO. Planet: Education for Environmental Sustainability and Green Growth. Global Education Monitoring Report; UNESCO: Paris, France, 2016. Available online: http:/ / unesdoc.unesco.org/images/0024/002464/ 246429e.pdf (accessed on 4 June 2018).

17. European Union (EU). The Bologna Declaration of 19 June 1999; Joint Declaration of the European Ministers of Education; European Union: Brussels, Belgium, 1999.

18. Lambrechts, W.; Van Petegem, P. The interrelations between competences for sustainable development and research competences. Int. J. Sustain. High. Educ. 2016, 17, 776-795. [CrossRef]

19. EHEA. European Higher Education Area. Secretaria General de Universidades. Gobierno de España. Ministerio de Educación; Guía del Usuario del ECTS: Brussels, Belgium, 2009.

20. Albareda Tiana, S.; Alférez Villarreal, A. A collaborative programme in sustainability and social responsibility. Int. J. Sustain. High. Educ. 2016, 17, 719-736. [CrossRef]

21. Lambrechts, W.; Mulà, I.; Ceulemans, K.; Molderez, I.; Gaeremynck, V. The integration of competences for sustainable development in higher education: An analysis of bachelor programs in management. J. Clean. Prod. 2013, 48, 65-73. [CrossRef]

22. Rieckmann, M. Future-oriented higher education: Which key competencies should be fostered through university teaching and learning? Futures 2012, 44, 127-135. [CrossRef]

23. CRUE-Sustainability. Guidelines for the Inclusion of Sustainability in the Curriculum. 2012. Available online: http:/ / www.crue.org/Documentos\%20compartidos/Declaraciones/Directrices_Ingles_ Sostenibilidad_Crue2012.pdf (accessed on 5 May 2018).

24. Tilbury, D. Education for Sustainable Development: An Expert Review of Processes and Learning; UNESCO: Paris, France, 2011. Available online: http:/ / unesdoc.unesco.org/images/0019/001914/191442e.pdf (accessed on 3 June 2018).

25. Ramos, T.B.; Caeiro, S.; van Hoof, B.; Lozano, R.; Huisingh, D.; Ceulemans, K. Experiences from the implementation of sustainable development in higher education institutions: Environmental Management for Sustainable Universities. J. Clean. Prod. 2015, 106, 3-10. [CrossRef]

26. O’Byrne, D.; Dripps, W.; Nicholas, K.A. Teaching and learning sustainability: An assessment of the curriculum content and structure of sustainability degree programs in higher education. Sustain. Sci. 2015, 10, 43-59. [CrossRef]

27. Bertschy, F.; Künzli, C.; Lehmann, M. Teachers' Competencies for the Implementation of Educational Offers in the Field of Education for Sustainable Development. Sustainability 2013, 5, 5067-5080. [CrossRef]

28. Leal Filho, W.; Manolas, E.; Pace, P. The Future We Want: Key issues on sustainable development in higher education after Rio and the UN decade of education for sustainable development. Int. J. Sustain. High. Educ. 2015, 16, 112-129. [CrossRef]

29. Sleurs, W. (Ed.) Competencies for ESD (Education for Sustainable Development) Teachers. A Framework to Integrate ESD in the Curriculum of Teacher Training Institutes. Comenius 2.1 Project 118277-CP-1-2004-BE-Comenius-C2.1. Brussels. 2008. Available online: https://platform.ue4sd.eu/ downloads /CSCT_Handbook_11_01_08.pdf (accessed on 8 June 2018).

30. UNITED NATIONS. The future we want: Outcome document of the United Nations Conference on Sustainable Development Adopted at Rio+20. 2012. Available online: https://sustainabledevelopment.un. org/content/documents/733FutureWeWant.pdf (accessed on 28 June 2018).

31. Brundiers, K.; Wiek, A. Do We Teach What We Preach? An International Comparison of Problem- and Project-Based Learning Courses in Sustainability. Sustainability 2013, 5, 1725-1746. [CrossRef] 
32. Leal Filho, W.; Shiel, C.; Paço, A. Implementing and operationalising integrative approaches to sustainability in higher education: The role of project-oriented learning. J. Clean. Prod. 2016, 133, 126-135. [CrossRef]

33. Albareda-Tiana, S.; Ruíz-Morales, J.; Azcárate, P.; Valderrama_Hernández, R.; Múñoz, J.-M. The EDINSOST Project: Implementing the Sustainable Development Goals at University level. In Universities as Living Labs for Sustainable Development: Supporting the Implementation of the Sustainable Development Goals; Leal Filho, W., Salvia, A.L., Pretorius, R., Brandli, L., Manolas, E., Alves, M.F.P., Azeiteiro, U., Rogers, J., Shiel, C., Paço, A., Eds.; Springer: Berlin, Germany, 2019.

34. Miller, G.E. The assessment of clinical skills/competence/performance. Acad. Med. 1990, 65 (Suppl. 9), 63-67. [CrossRef]

35. National Center for Education Statistics. Defining and Assessing Learning: Exploring Competency-Based Initiatives. U.S. Department of Education, 2002. Available online: https:/ / nces.ed.gov/pubsearch/pubsinfo. asp?pubid=2002159 (accessed on 9 June 2018).

36. UNESCO. Education for Sustainable Development Sourcebook. Education for Sustainable Development in Action. Learning Training Tools N_4-2012; United Nations Educational, Scientific and Cultural Organization: Paris, France, 2012.

37. Varela-Losada, M.; Pérez-Rodríguez, U.; Álvarez-Lires, J.; Álvarez-Lires, M. Desarrollo de competencias docentes a partir de metodologías participativas aplicadas a la Educación Ambiental [Developing teaching competences through participative methodologies on Environmental Education]. Formac. Univ. 2014, 7, 27-36. [CrossRef]

38. UNESCO. Rethinking Education Towards a Global Common Good? United Nations Educational, Scientific and Cultural Organization: Paris, France, 2015; Available online: http:/ / unesdoc.unesco.org/images/0023/ 002325/232555e.pdf (accessed on 10 June 2018).

39. Wals, A.E.J.; Blewitt, J. Third Wave Sustainability in Higher Education: Some (Inter)National Trends and Developments; Jones, P., Selby, D., Sterling, S., Eds.; Green Infusions: Embedding Sustainability across the Higher Education Curriculum: London, UK, 2010.

40. Brundiers, K.; Wiek, A.; Redman, C.L. Real-world learning opportunities in sustainability: From classroom into the real world. Int. J. Sustain. High. Educ. 2010, 11, 308-324. [CrossRef]

41. Wiek, A.; Xiong, A.; Brundiers, K.; van der Leeuw, S. Integrating problem- and project-based learning into sustainability programs. Int. J. Sustain. High. Educ. 2014, 15, 431-449. [CrossRef]

42. Steiner, G.; Posch, A. Higher education for sustainability by means of transdisciplinary case studies: An innovative approach for solving complex, real-world problems. J. Clean. Prod. 2006, 14, 877-890. [CrossRef]

43. SDSN Australia/Pacific. Getting Started with the SDGs in Universities: A Guide for Universities, Higher Education Institutions, and the Academic Sector. Australia, New Zealand and Pacific Edition. Sustainable Development Solutions Network-Australia/Pacific, Melbourne. 2017. Available online: https:/ /ap-unsdsn. org/wp-content/uploads /2017/08/University-SDG-Guide_web.pdf (accessed on 7 June 2018).

(C) 2018 by the authors. Licensee MDPI, Basel, Switzerland. This article is an open access article distributed under the terms and conditions of the Creative Commons Attribution (CC BY) license (http:/ / creativecommons.org/licenses/by/4.0/). 